Ethiopian Journal of Environmental Studies \& Management 9 (1): 35 - 44, 2016.

ISSN:1998-0507

Submitted: July 21, 2015

doi: http://dx.doi.org/10.4314/ejesm.v9i1.4

Accepted: January 09, 2016

\title{
FLOOD VULNERABILITY: IMPENDING DANGER IN SABON-GARI MINNA, NIGER STATE, NIGERIA
}

\author{
ADELEYE, B.M. ${ }^{1}$ AND *AYANGBILE, 0.A. ${ }^{2}$ \\ ${ }^{1}$ Department of Urban and Regional Planning, Federal University of Technology, Minna, \\ Niger State, Nigeria \\ ${ }^{2}$ Department of Urban and Regional Planning, University of Ibadan, Nigeria
}

\begin{abstract}
This study examines the vulnerability of buildings to flooding and the danger posed at Sabo Gari area of Minna, Niger State. Sabon-Gari which is one of the 22 neighborhoods found in Minna is a highly populated area as people who cannot afford to stay in the low density areas (Government Reserve Area - G.R.A) move to this area in search for cheap accommodation and this has created a lot of housing need amongst the resident of SabonGari. High demand for housing in the study area has prompted the landowners and developers to develop their properties with little or no regard for Government approved codes and standards. Indiscriminate development and erection of buildings along water ways make the inhabitants of such buildings highly vulnerable to flooding during high precipitation. A quick bird image which is a panchromatic of 65 centimeter pixel resolution was used for the study. A vulnerability assessment was carried out using ArcGis 10 software and a vulnerability map was prepared showing the vulnerable buildings within the study area. The coping strategies employed by the inhabitants ofSabon-Gari were also identified through Questionnaires administered. The buildings along the river channels were marked and the study reveals that danger looms in the study area with respect to flood. The result of analysis suggests that quick mitigating efforts be put in place to avert and or reduce this impending disaster. Hence, certain structures on waterways needs to be demolished, silted drainages should be cleared and stiffer measure be put in place by law enforcement agency to check the problem of indiscriminate waste disposal in drainages.
\end{abstract}

Key Words: Vulnerability, Geospatial, Mitigation, Digital Elevation Model, Flood

\section{Introduction}

Flooding is one of the most devastating natural phenomena in the world claiming lives, destroying properties and displacing many. According to Harris (2001) flooding has claimed millions of lives in the last hundred years alone, more than any other weather natural phenomenon. In Nigeria, the National Emergency Management
Agency (NEMA), (2013) reported that a total of 7.7 million people were affected by flooding in the year 2012, of which 2.1 million were officially registered across the country as internally displaced persons and over 300 people were killed during that period (NEMA, 2013). The 2012 flood affected about 23 States of the Federation with Niger State inclusive. The Niger State

*Corresponding Author: Ayangbile, O.A.

Email: bukiayangbile@yahoo.com 
Emergency Agency (NSEMA) (2012) in her report disclosed that over 1000 families and 47 persons were displaced and killed respectively, by the flood which affected over 500 communities across the State (NSEMA, 2012). It was reported that the flood incident has been the worst natural disaster the country has experienced since 1936 (West Africa insight, 2012). There has been an increase in recognition by both governments and multilateral agencies of the need to mainstream flood risk reduction into development plans.

Nigeria's (2003) agenda 21 document spelt out objectives to combat floods which include providing a master plan for flood control and relief measures for victims; mitigate floods through the relevant land use laws and edicts; improve institutional capacity for flood prediction and public awareness programmes and minimize the impact of floods through the provision and maintenance of appropriate infrastructure (Nabegu, 2014). However, there is little effort by government to systematically treat risk reduction from floods as an integrated, cross-sectoral objective. Instead, they have dealt with flood risk primarily within the very narrow framework of flood control, improved preparedness, relief and rehabilitation and preparedness capabilities and expose support to affected groups. Thus, flood hazards continue to cause great damage to infrastructure and loss of life. VanWestern and Hosfstee (2000) opined that Mitigation of flood disaster can be successful only when detailed knowledge is obtained about the expected frequency, character, and magnitude of hazardous events in an area as well as the vulnerability of the people, buildings, infrastructures and economic activities in a potential dangerous area. Often times these detailed knowledge is always lacking in most urban centres of the developing world especially Nigeria (Ishaya et al., 2008a and Ifatimehin et al., 2006). According to Ishaya et al. (2009), one way to mitigate the effects of flooding is to ensure areas vulnerable to flood are identified and adequate precautionary measures taken to ensure either or all of adequate preparedness, effective response, quick recovery and effective prevention.

In-spite of government's effort in flood mitigation, the residents of Sabon-Gari has failed to learn from the raging flood experience that once besieged the state. Increase in agglomeration and competition for building space has led to unguided planning, building contraventions along water ways, indiscriminate waste disposal in water channels and silted drains has made the study area; " Sabon-Gari" highly vulnerable to flooding. Over the years Geographic Information System has been used in flood assessment and this has proven effective. According to Jayasselan (2006) and Ishaya et al. (2009), an integrated approach of Remote Sensing (RS) and Geographic Information System (GIS) has proved to be the most effective (Jayasselan, 2006), and perhaps the only option to flood hazard preparedness and to reduce potential risk. It is against this background that this paper tends to assess flood vulnerability in Sabon-Gari area of Minna, Niger State using Geographic Information System as a tool.

\section{Aims and Objectives}

i. Map the vulnerable areas using Digital Elevation Model and satellite imageries,

ii. Carry out spatial analysis of the flood prone areas in Sabon-Gari,

iii. Determine the number of buildings vulnerable to flooding and create a vulnerability map, 
iv. Suggest strategies to ameliorate for future flood disaster and risk mitigation in the study area.

\section{Study Area}

Sabon-Gari ('Strangers' Quarters' or literally 'New Town' in Hausa language) is one of the 22 neighborhoods of Minna, Niger State. Sabon-Gari is located on Latitude $9^{\circ} 37^{\prime} \mathrm{N}$ and Longitude $6^{\circ} 33^{\prime} \mathrm{E}$. Figure 1 highlights the study area within the Map of Minna and Figure 2 shows
Sabon-Gari within the Street Guide Map of Minna. The typical climate of the middle belt zone of Nigeria is a good reflection of Sabon-Gari's climate, with rain season beginning around April and lasting till October with a mean annual rainfall of $1334 \mathrm{~mm}$ (52 inches). The mean monthly temperature is highest in March at $30.5^{\circ} \mathrm{C}$ $\left(85^{\circ} \mathrm{F}\right)$ and lowest in August at $22.03{ }^{\circ} \mathrm{C}$ $\left(72^{\circ} \mathrm{F}\right)$.

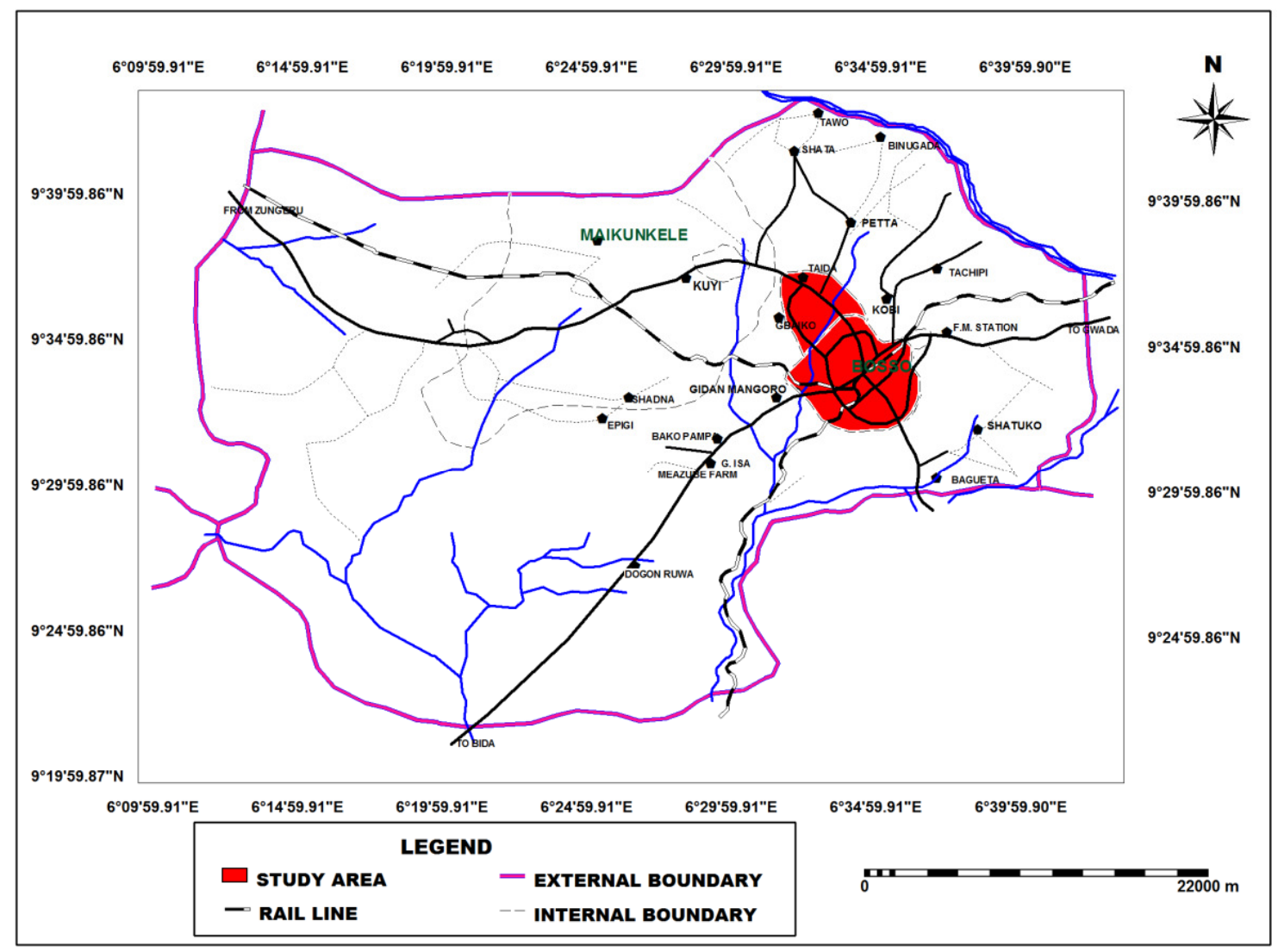

Figure 1: Map of Minna Showing Study Area

Source: Department of urban and Regional planning, FUTMINNA. 




Figure 2:Sabon-Gari Highlighted in the Street Guide Map of Minna.

Source: Department of urban and Regional planning, FUTMINNA.

\section{Methodology}

Geospatial based techniques were used in the research. At the first phase, several points (X,Y, and $\mathrm{Z}$ data) were picked at regular interval on Google earth application in other to determine the terrain 
of the study area. These data (X, Y and Z) were recorded in excel sheet and was then imported to Surfer 11 software where the contour map for the study area was plotted. Topographic map plotted was exported to Ilwis 3.3 Academic software and was converted to segments map where the contour were digitized and interpolated to generate digital Elevation Model (DTM).

At the Second phase, A buffer of 15 metres (the government Approved Setbacks for Gorges, water Channels and Drains) was created on the subset image of the study area using the "Arc tool box" on Arcgis 10.0. A flow accumulation model was created using the DEM, thus various class of risk were created.

\section{Field Survey}

Interviews were conducted with residents of Sabon-Gari area in reaching adequate conclusions and making relevant recommendations. The interview involved 40 respondents drawn from four areas within the neighborhood; that is, Old Kure market, AngwanKaje, Sabon- Gari Neighborhood and Kuta Garage. Multistage sampling technique was adopted in selecting the interviewees. GPS was also used to acquire data on the point of distinguishing land use and points of elevation

\section{Data Processing Techniques}

The data processing techniques adopted for this research include: Data evaluation, Buffering, Geo-referencing, Data sub-setting, Terrain modeling, water body and settlement update from satellites images and integration.

\section{Results and Discussion}

To fulfill the aim of this research, some analyses were carried out. The digitized contour map was interpolated to generate the Digital Terrain Model (DTM) for Sabon-Gari. This is shown in figure 3 and figure 4 respectively. The DTM shows the slope characteristics and the elevations of the study area which ranges from $254.0 \mathrm{~m}$ to $256.0 \mathrm{~m}$ above sea level. The DTM shows that the lowest elevation (254.0M) is found along the major water channel south ward. While the other low elevations (254.4 $\mathrm{M}$ and $254.8 \mathrm{M})$ are found along other water tributaries within the study area. The mapped DTM also shows the highly flood vulnerable areas falling between $254.0 \mathrm{M}$ to $254.8 \mathrm{M}$ above sea level and this reveals that ample of the lands in the study area are on a low elevation and this makes the area vulnerable to flooding. 


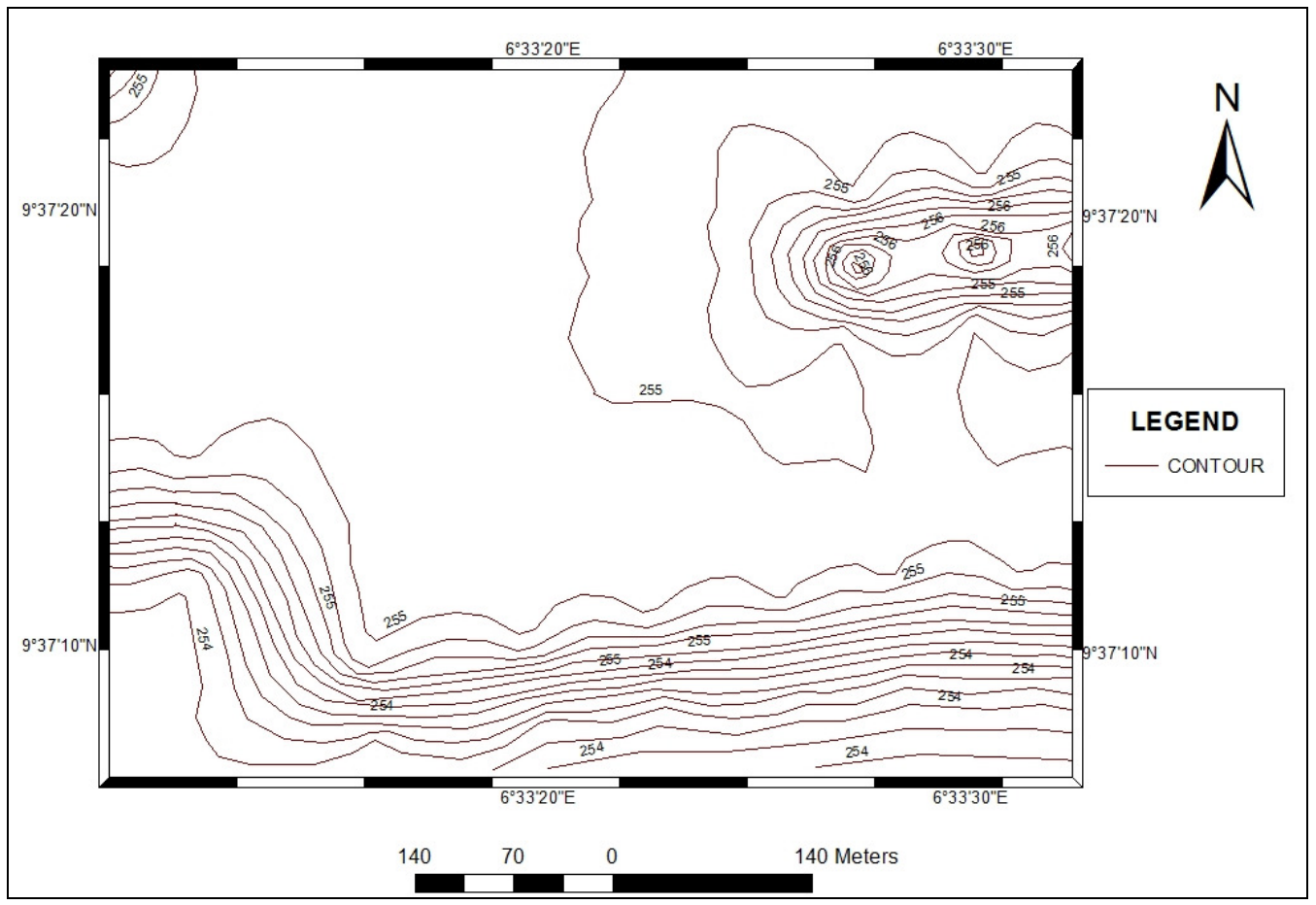

Figure 3: Topographic Map of the Study Area

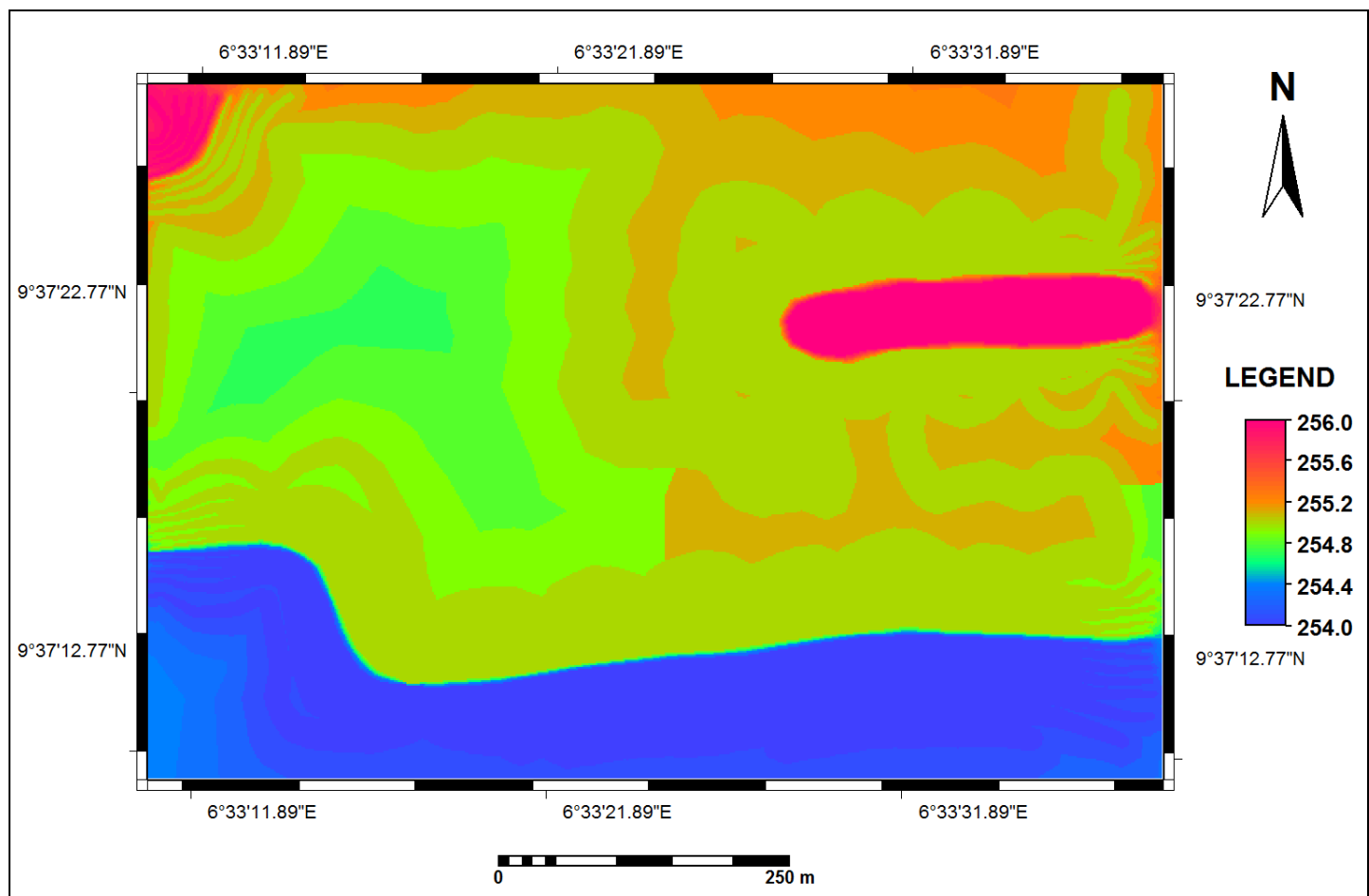

Figure 4: Digital Terrain Model for the Study Area.

To determine the number of buildings vulnerable to flooding in the study area, a buffer of 15 meters which is the state government approved set-back for Canals, 
Gorges and drainages was created along all the water ways within the study area using ARCGIS 10.0 software. Buildings that falls within the buffer created were digitized and were termed as vulnerable buildings. More so, these buildings are said to be contravening the approved building set-back designated by the state government. A total of 254 buildings fall within the buffer and these buildings are said to be highly vulnerable and are represented in colour red; this is shown in Figure 5.

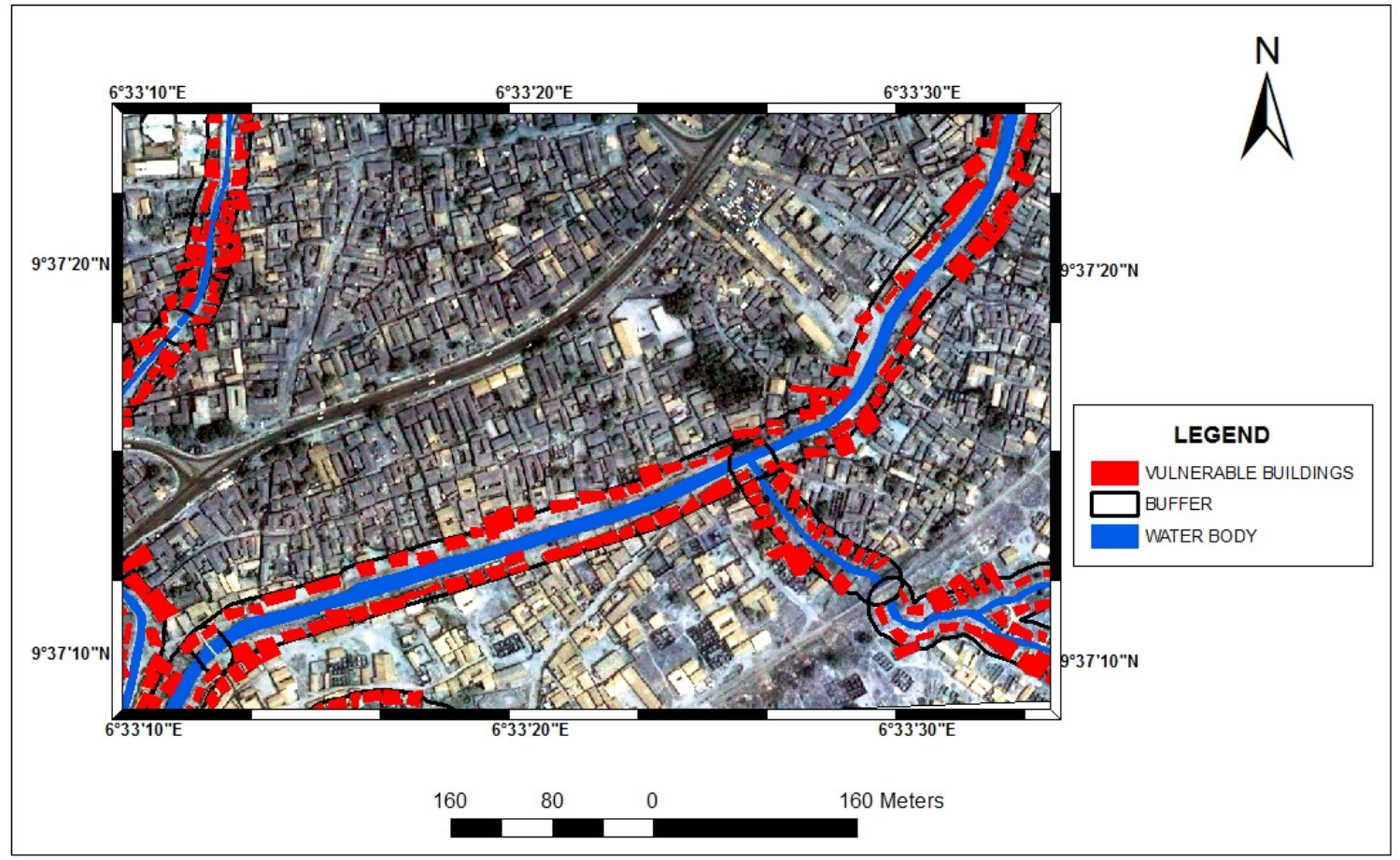

Figure 5: Vulnerable Buildings in Sabon-Gari.

To determine the level of vulnerability in the study area a flow analysis was carried out to know the natural drainage pattern of the study area and an overlay analysis was also carried out to determine buildings on low and high elevations in other to ascertain the buildings at high risk, moderate risk and low risk. Figure 6 shows the level of vulnerability in the study area. Areas at high risk are represented in red while areas at moderate risk and low risk are represented with yellow and green respectively. 


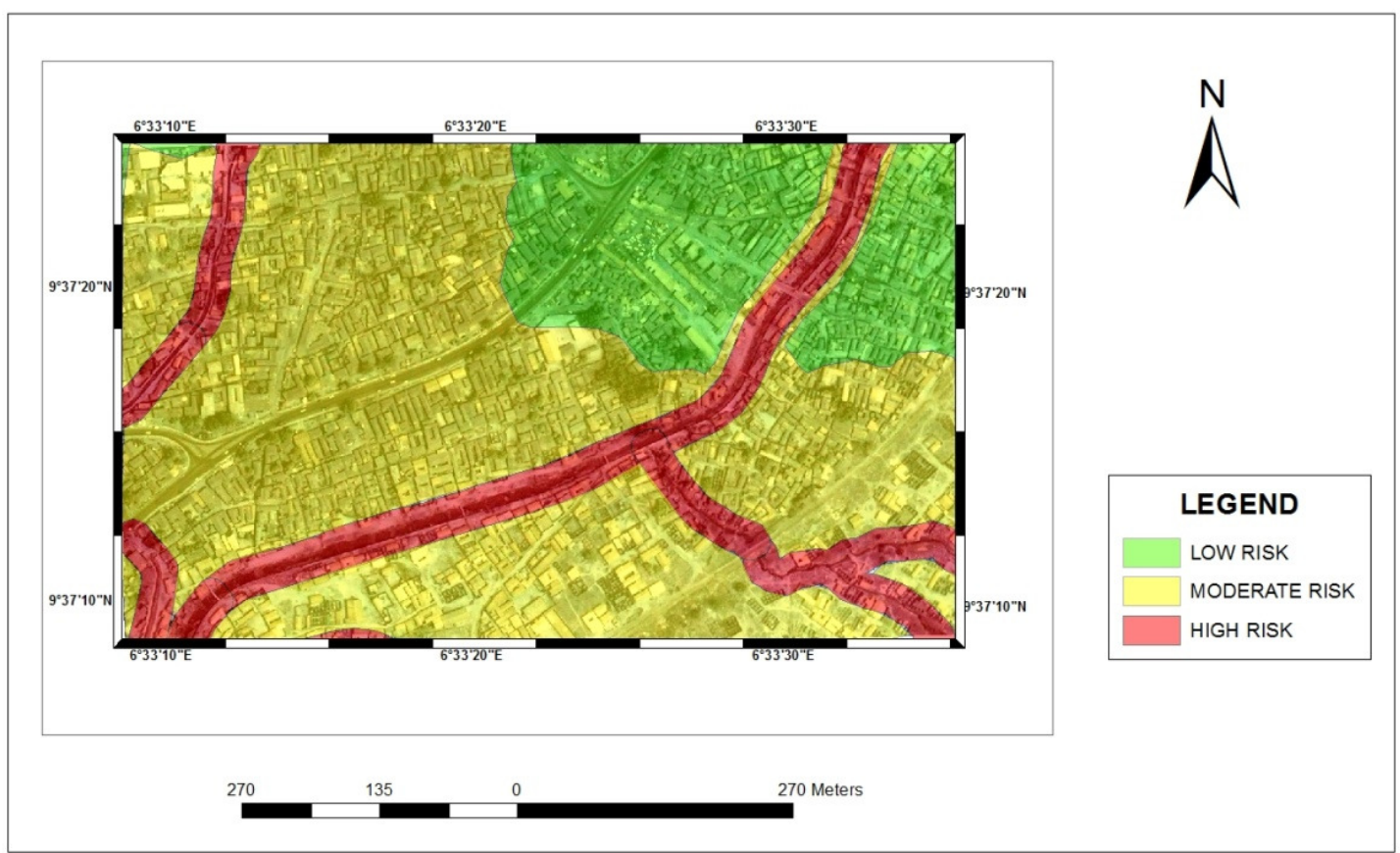

Figure 6: Vulnerability Map in Sabon-Gari

Table 1: Level of Vulnerability

\begin{tabular}{lll}
\hline Class & Area $\left(\mathbf{M}^{2}\right)$ & Percentage \\
\hline High Risk & 79586.28 & 15.9 \\
Moderate Risk & 281571.00 & 53.38 \\
Low Risk & 166350.00 & 31.54 \\
Total & 527507.28 & 100 \\
\hline
\end{tabular}

From the table above (4.1), 15.9\% of the buildings in the study area are at high risk of flooding. The buildings in this category give little or no regard for the mandatory building setbacks from the water channel. Thus, these buildings are located along water channels on lands with low elevation. The buildings designated as high risk constitute $79586.28 \mathrm{M}^{2}$ of the total land area.

A number of buildings were identified as buildings with moderate risk vulnerability to flooding. Distance from the water channel is relatively safe and only in the event of high volume of runoff from the water channel can these buildings be prone to the risk. These buildings are also located on lands with low elevation however the distance of these buildings from the water channels makes them less vulnerable to flooding. Buildings in this category occupy a total land area of $281571 \mathrm{M}^{2}$. Low risk buildings constitute $31.54 \%$ of the total buildings in the study area with total land coverage of 166350 $\mathrm{M}^{2}$. These buildings (low risk) are located on high elevation.

During the field observation it was discovered that ample of the buildings in the study area are located on flood plains with their drainages either silted or used as refuse collection points during dry season. This illicit act exposes Sabon-Gari to an impending danger of flooding. The research conducted interviews to substantiate the findings of the GIS 
analysis. Result of the interview shows that $62 \%$ of the respondents expressed knowledge of the risk posed by flooding before acquiring properties (land) and settling along water channel. The respondents stated that they were forced to acquire property along the water channels as a result of high cost of accommodation in the low density area. These respondents also believe that an impending flooding and heavy precipitation may put them at a risk of losing their lives and properties but they pray that such an occurrence should not happen.

A number of the residents $(31 \%)$ at Sabon-Gari take proactive steps in mitigating the adverse effect of flooding during rainy season by employing common measures such as: clearing of drainages and use of sand bags for flood breaks.

$69 \%$ of the respondents attributed their inability to employing mitigation strategy to lack of funds. It is a pity to note $35 \%$ of the respondents are still not knowledgeable about the dangers that accompany flooding.

\section{Conclusion}

The study successively created a vulnerability map thus a number (254) of vulnerable buildings were identified. Areas lying along the water channels within Sabon-Gari are at locations that are most vulnerable to flood. Rapid agglomeration of people and low cost of accommodations has led to the erection of illegal structures along water channels; Danger lies ahead if early mitigation measures are not put in place.

\section{Recommendations}

The following are hereby recommended as a way forward in ameliorating future occurrence of flood hazards in Sabon-Gari:
Stiffer measure should be put in place by law enforcement agency to check the problem of indiscriminate waste disposals in drainage. Adequate Skip bin should be provided in strategic locations for easy access by the Niger State Environmental Protection Agency.

Buildings along water channels should be demolished and the government approved setbacks should strictly adhere to. More so residents should be strongly discouraged from settling within the flood plains.

Silted drainages should be cleared, embankments and other structural flood control measures should be constructed at areas of high risk.

Public awareness campaigns should be organized by government and NGOs in sensitizing the residents of Sabon-Gari on the dangers of flooding and the problems that accompany it.

\section{References}

Adeleye, B.M. and Ayangbile, O.A. (2014). Flood Vulnerability: Impending danger in SabonGariMinna, Niger State. Paper presented at the $50^{\text {th }}$ ISOCARP Conference, Gdynia, Poland, $23^{\text {rd }}$ $26^{\text {th }}$ September, 2014.

Harris, T. (2001). How flood work. www.howstuffworks.com. accessed 27th April, 2014.

Ifatimehin, O.O. and Ufuah, M.E. (2006). An Analysis of urban expansion and loss of vegetation in Lokoja, Using GIS Techniques. Zaria Geographers, 17(1):28-36

Ishaya, S., Ifatimehin, O. and Okafor, C. (2008a). Remote sensing and GIS applicationin urban expansion and loss of vegetation cover in kaduna town, Northern Nigeria. American- 
Eurasian Journal of Sustainable Agriculture, 2(2): 117-124.

Ishaya, S. Ifatimehin, O.O. and Abaje, I. B., (2009). Mapping Flood Vulnerable Areas in Developing Urban Centre of Nigeria, Journal of Sustainable Development in Africa, 11(4):180-194.

Jayasselan, A.T. (2006). Drought and Floods Assessment and Monitoring Using Remote Sensing and GIS [Electronic Version]. Satellite Remote Sensing and GIS Application in Agricultural Meteorology, 291313.

Nabegu, A.B. (2012). Analysis of Vulnerability to Flood Disaster in Kano State, Nigeria, Greener Journal of Physical Sciences, ISSN: 22767851 ICV 2012: 5.88
Niger State Emergency Agency (NSEMA), (2012). Flood kills over 47 in Niger State. An Article posted in the Channels News. www.channelstv.com, accessed 14 April, 2014.

Nigeria Emergency Management Agency NEMA (2013). Flood Disaster report 2012, Daily Trust Newspaper, 11th May, 2012.

Van Western, C.J. and Hosfstee, F. (2000). The role of remote sensing and GIS in risk mapping and damage assessment for disasters in urban areas. Fernerkundung und Naturkatastrophen, 7: 442-450.

West Africa Insight (2012). A Year of Raging floods, Special Report. October 2012. 